\title{
Conventional and Microwave Assisted Synthesis of New Triazole Derivatives and Evaluation of Their Antimicrobial Activities
}

\section{Yeni Triazol Türevlerinin Konvansiyonel ve Mikrodalga Destekli Sentezi ve Antimikrobiyel Aktivitelerinin Değerlendirilmesi}

\author{
Zeynep Özdemir ${ }^{1^{*}}$, Inci Selin Doğan ${ }^{\circledR}$, Mehmet Abdullah Alagöz ${ }^{1 \oplus}$, Hasan Erdinç Sellitepe ${ }^{2}$, Didem Kart ${ }^{3}$ \\ ${ }^{1}$ Inönü University, Faculty of Pharmacy, Department of Pharmaceutical Chemistry, Malatya/Turkey. \\ ${ }^{2}$ Karadeniz Teknik University, Faculty of Pharmacy, Department of Pharmaceutical Chemistry, Trabzon/Turkey. \\ ${ }^{3}$ Hacettepe University, Faculty of Pharmacy, Department of Pharmaceutical Microbiology, Ankara/Turkey.
}

\section{ABSTRACT}

$\mathrm{n}$ this study, four new oxime ether derivatives were synthesized and their antimicrobial activities were evaluated. At the same time, a comparison of the efficiency of the conventional method of synthesis with the microwave method was investigated. The structures of synthesized compounds were confirmed by their IR, ${ }^{1} \mathrm{H}-\mathrm{NMR}$, and HRMS spectra. Antimicrobial activity of the compounds was tested against two $\mathrm{Gr}(+)$ bacteria (S. aureus, E. faecalis), two Gr (-) bacteria (P. aeruginosa, $E$. coli), and three yeast-like fungi (C. albicans, C. krusei, C. parapsilosis) by modified agar dilution method.

\section{Key Words}

Triazole, oxime ether, microwave synthesis, antimicrobial activity.

\footnotetext{
Unulan bu çalışmada oksim eter türevi dört yeni bileşik sentezlenmiş ve antimikrobiyal aktiviteleri değerlendirilmiştir Aynı zamanda, geleneksel yöntem ile mikrodalga yöntemi karşılaştırılmasının incelenmesi amaçlanmıştır. Sentezlenen bileşiklerin yapısı IR, ${ }^{1} \mathrm{H}-\mathrm{NMR}$ ve HRMS spekturumları ile doğrulanmıştır. Bileşiklerin antimikrobiyal aktivitesi, iki Gr (+) (S. au reus, E. faecalis) ve iki Gr (-) bakteri (P. aeruginosa, E. coli) ve mantar benzeri üç mayaya (C. albicans, C. krusei, C. parapsilosis) karşı agar mikrodilüsyon yöntemi kullanılarak değerlendirilmiştir.
}

\section{Anahtar Kelimeler}

Triazol, oksim eter, mikrodalga sentez, antimikrobiyal aktivite. 


\section{INTRODUCTION}

$\Lambda$ ntibacterial and antifungal agents are an important part of anti-infective drugs and have been used in clinical practice for a long time. Serious bacterial and fungal infections occur in immunocompromised patients, and it is necessary to treat these infections with effective antimicrobial agents due to the increase in probability of resistance [1-4]. The use of medical devices to improve quality of life and prolong survival, such as joint prostheses and cardiac devices, may also lead to increased opportunistic fungal infections. In addition, antifungal drugs are generally more toxic than antibacterial drugs mainly because fungal cells are eukaryotic, like mammalian cells [5]. For these reasons, efforts to develop new potent and effective antimicrobial compounds with fewer side effects are important for controlling serious infections in patients with malignancy, surgical operations, and immune deficiency.

Therefore, development of new antifungal agents with better activity profile is an attractive area for medicinal chemists. The azole group of antifungals are a rapidly expanding family of antifungal drugs and have maintained a key role in the treatment of immunocompromised patients who need oral therapy [6]. Triazole derivatives have a special importance among the azole derivatives. Fluconazole, itraconazole, and terconazole are examples of antifungal drugs in the market which have a triazole ring in their structure. Previously, we prepared some new 1-(2-naphtyl)-2-(1,2,4-triazole-1$\mathrm{yl}$ )oxime ether derivatives and found that most of the these compounds showed promising antimicrobial ac- tivity at low concentration (16 $\mu \mathrm{g} / \mathrm{mL})$ [7]. Also, pyrazole derivatives have been defined as heterocyclic compounds which have significant antimicrobial effects in literature [8-11]. Previously, we prepared some new 1-(naphtalene-2-yl)-2-(1H-pyrazol-1-yl)ethanone oxime ether derivatives and found that most of these compounds showed antifungal activity at low concentration $(12.5 \mu \mathrm{g} / \mathrm{mL})$ [12].

In our previous studies, different oxime ether compounds with (aryl)alkyl azole derivatives have been synthesized, and the relationship between structure and antibacterial and antifungal activity has been investigated [12-15]. In the (aryl)alkyl azole derivatives, naphthalene and phenyl rings are used as the aryl group, and imidazole, pyrazole and triazole rings are used as the azole group. In one of these studies, a series of oxime ether naphthylimidazole derivative was synthesized and antimicrobial activities were assessed; the compounds synthesized were found to be effective against S. aureus, C. albicans, and C. krusei at doses of 0.5 and 1 $\mu \mathrm{g} / \mathrm{mL}$ respectively (Figure 1) [13].

In addition to these studies, naphthylpyrazole oxime ethers were synthesized, and all of the compounds displayed antifungal activity against both $C$. albicans and C. tropicalis, with lower MIC values $(12.5-50 \mu \mathrm{g} /$ $\mathrm{mL}$ ). 1-(naphtalene-2-yl)-2-(1H-pyrazol-1-yl)ethanone $\mathrm{O}$-methyl oxime and 1-(naphtalene-2-yl)-2-(1H-pyrazol1 -yl)ethanone $O$-butyl oxime were found to be the most active compounds against $C$. tropicalis at $12.5 \mathrm{~g} / \mathrm{mL}$ concentration (Figure 2) [12].

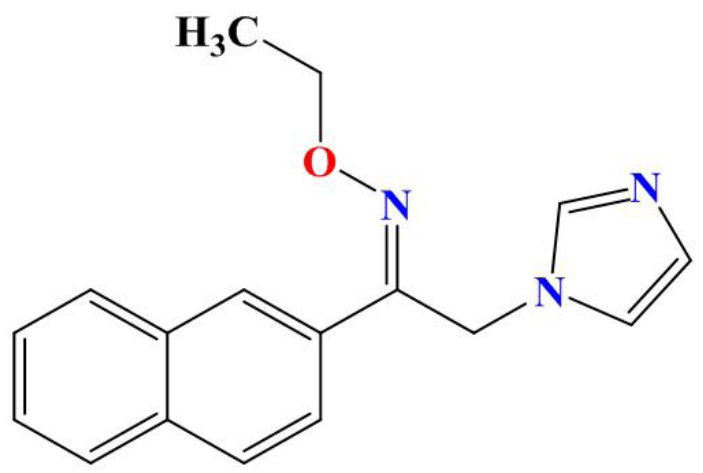

Figure 1. Structure of an (aryl)alkyl azole oxime ether [13]. 

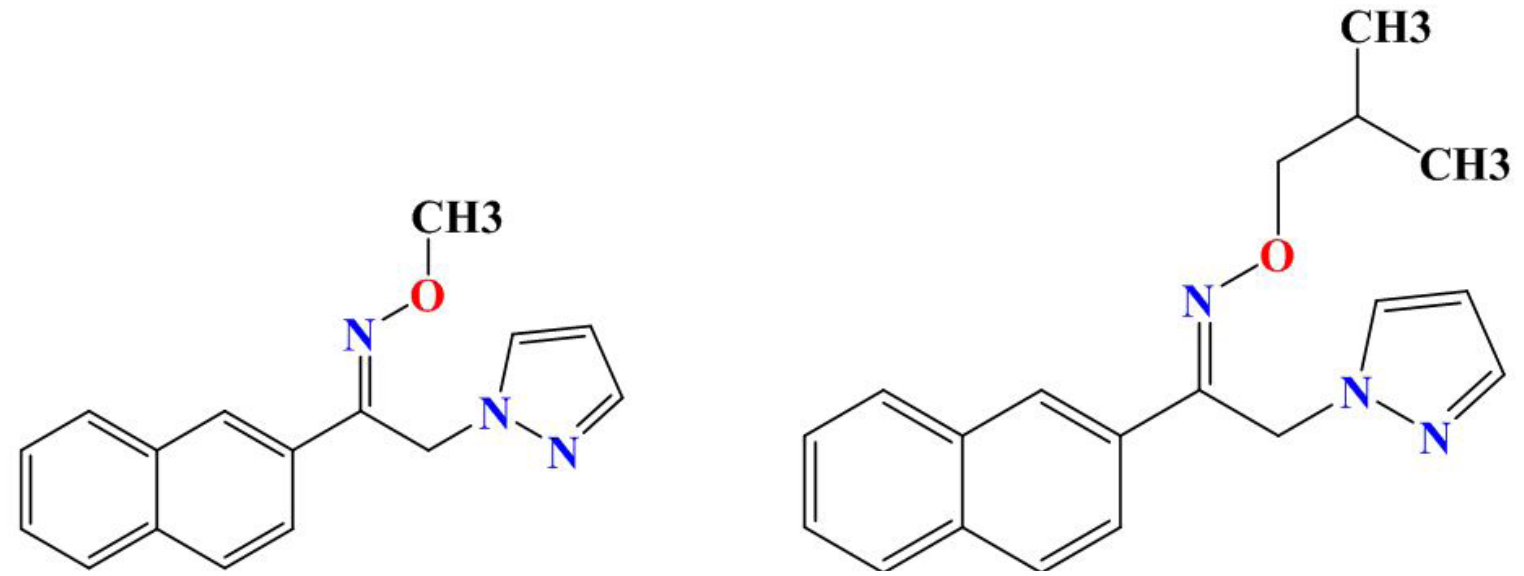

Figure 2. Structure of 1-(naphtalene-2-yl)-2-(1H-pyrazol-1-yl)ethanone 0 -methyl oxime and 1-(naphtalene-2-yl)-2-(1H-pyrazol-1-yl) ethanone $O$-butyl oxime [12].

In another study, oxime ester derivatives were synthesized with phenyl/4-chlorophenyl ring as an aryl group and the imidazole ring as the azole group, and it was observed that these compounds had a very high antimicrobial and antifungal effect. The most active compounds against $S$. aureus and E. faecalis were 2-(1H-imidazol-1yl)-1-phenylethyl 4-phenylbutanoate, 2-(1H-imidazol1-yl)-1-phenylethyl cinnamate, and 1-(4-chlorophenyl)2-(1H-imidazol-1-yl)ethyl 4-oxo-4-phenylbutanoate (MIC $=8 \mu \mathrm{g} / \mathrm{mL})$ and 2-(1H-imidazol-1-yl)-1-phenylethyl 2-propylpentanoate, 2-(1H-imidazol-1-yl)-1-phenylethyl cyclohexanecarboxylate, and 1-(4-chlorophenyl)-2(1H-imidazol-1-yl)ethyl 2-propylpentanoate (MIC= 32 $\mu \mathrm{g} / \mathrm{mL})$, respectively. The MIC value of 2-(1H-imidazol1-yl)-1-phenylethyl

[1,1'-biphenyl]-4-carboxylate was $0.125 \mathrm{mg} / \mathrm{mL}$ against C. albicans. Additionally,
1-(4-chlorophenyl)-2-(1H-imidazol-1-yl)ethyl pentanoate $(\mathrm{MIC}=0.25 \mathrm{mg} / \mathrm{mL})$ was potent against resistant $C$. glabrata, a fungal strain less susceptible to some firstline antifungal drugs (Figure 3) [14].

These studies have shown that antimicrobial activity is significantly enhanced by the presence of the phenyl ring instead of the naphthalene ring in arylalkyl azole derived oxime ethers. The azole group, imidazole, and triazole rings were found to increase activity more than the pyrazole ring.

Microwave-assisted synthesis-with its short reaction time and high-efficiency yield-has attracted a lot of attention in recent years [16-18]. In microwave-assisted synthesis, microwave irradiation causes the tem-

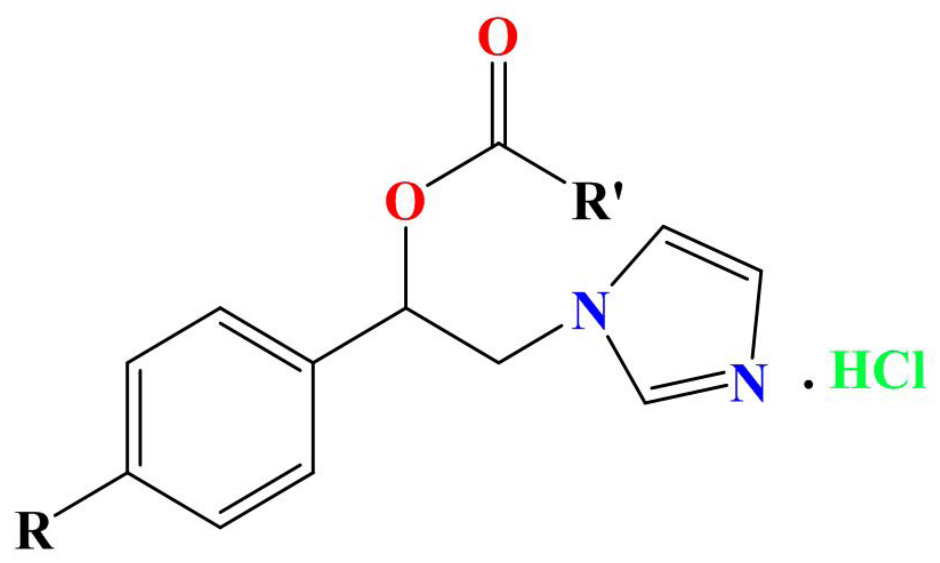

Figure 3. General structure of compounds $\mathrm{R}: \mathrm{H}, \mathrm{Cl} ; \mathrm{R}^{\prime}: \mathrm{CH}\left(\mathrm{CH}_{2} \mathrm{CH}_{2} \mathrm{CH}_{3}\right)_{2} ; \mathrm{CH}_{2} \mathrm{CH}_{2} \mathrm{CH}_{2} \mathrm{C}_{6} \mathrm{H}_{5} ; \mathrm{CH}=\mathrm{CHC} \mathrm{H}_{5} ; \mathrm{C}_{6} \mathrm{H}_{11} ; \mathrm{C}_{6} \mathrm{H}_{4}-\mathrm{C}_{6} \mathrm{H}_{5} ; \mathrm{CH}_{2} \mathrm{CH}_{2} \mathrm{CH}_{2} \mathrm{CH}_{3}$; $\mathrm{CH}_{2} \mathrm{CH}_{2} \mathrm{COC}_{6} \mathrm{H}_{5}[14]$. 
perature of a whole reaction mixture to rise rapidly. In addition, it ensures that the reactions, especially those that take hours (or even days), take place within a shorter time [16-18]. Thus, microwave-assisted synthesis reactions are faster and more efficient than conventional methods for medicinal and organic chemists [19]. In this study, we synthesized the compounds by microwave-assisted synthesis in order to shorten the synthesis time of oxime ether compounds (which were completed in four hours by the conventional method), and to increase the yield obtained.

Therefore, in this study we aimed to design new oxime ether derivatives with a triazole ring and to evaluate their antifungal/antibacterial activities, and to synthe size the compounds using both the conventional and microwave methods. These compounds were designed by using alkyl or arylalkyl groups (Scheme 1) in order to evaluate the effect of the structural properties of the alkyl group on the activity. For this purpose, we focused on certain modifications of the alkyl group, such as altering the branching and length of it, in order to establish some relationships between the structure and the activity (Table 1 ).

\section{MATERIALS and METHODS}

\section{Chemistry}

\section{Materials}

The general synthesis was depicted in Scheme 1. All reagents and solvents were obtained from commercial suppliers. All reactions were monitored by analytical thin-layer chromatography using Merck pre-coated silica gel plates with $\mathrm{F}_{254}$ indicator. Column chromatography was performed using Merck silica gel 60 (230400 mesh ASTM) as stationary phase and chloroform/methanol (90:10 v/v) as solvent system. Melting points (mp) were determined using Thomas Hoover capillary melting point apparatus and are uncorrected. IR spectra were recorded on a Perkin Elmer Spectrometer by ATR technique. ${ }^{1} \mathrm{H}-\mathrm{NMR}$ spectra were recorded on a Brucker Avonce Ultrashield FT-NMR spectrometer in DMSO-d6 at $300 \mathrm{MHz}$ (in İnönü University, Malatya). Mass spectra were recorded on a LCMS-IT-TOF (Shimadzu, Kyoto, Japan) by using ESI method (in Anadolu University, Eskişehir). Microwave device is Perkin Elmer brand.

\section{Synthesis of compounds}

The compounds 1-(2-naphthyl)-2-bromoethanone, 1-(2-naphthyl)-2-(1,2,4-triazole-1-yl)ethanone, and 1-(2-naphthyl)-2-(triazole-1-yl)ethanone oxime were synthesized according to literature procedures [20-22].

\section{2-Bromo-1-naphthylethanone (A)}

To a solution of $50 \mathrm{mmol}(8.51 \mathrm{~g}) 2$-acethlnaphthalene in $50 \mathrm{ml}$ acetic acid in an ice bath: first 3 drops of $\mathrm{HBr}$ was added, then $50 \mathrm{mmol} \mathrm{Br}_{2}$ solution in $2.5 \mathrm{ml}$ acetic acid, dropwise, with constant stirring at $0-5^{\circ} \mathrm{C}$. After the bromine addition was complete, the mixture was stirred at room temperature for two hours. The reaction medium was poured into ice water, and the resulting precipitate was filtered, washed with sodium bicarbonate solution, dried in the dark, and purified by crystallization from methanol/water [20].

\section{1-Naphthyl-2-(1H-triazol-1-yl)ethanone (B)}

To a solution of $30 \mathrm{mmol}$ (2.07 g) 1,2,4-triazole in $2.5 \mathrm{ml}$ DMF: $10 \mathrm{mmol}$ (2.49 g) 2-bromo-1-naphthylethanone (A) solution in $2.5 \mathrm{ml} \mathrm{DMF}$ was slowly added, with constant stirring at $0-5^{\circ} \mathrm{C}$. The reaction mixture was stirred for two hours in an ice bath, then overnight at room temperature. The reaction medium was poured into ice water, and the resulting precipitate was filtered and purified by crystallization from ethyl acetate/ethanol [21].

\section{1-Naphthyl-2-(1H-triazol-1-yl)ethanone oxime (C)}

$15 \mathrm{mmol}$ (3.56 g) 1-Naphthyl-2-(1H-triazol-1-yl)ethanone (B) and $30 \mathrm{mmol}(2.08 \mathrm{~g}$ ) hydroxylamine hydrochloride were dissolved in $75 \mathrm{ml}$ ethanole and alkylated to $\mathrm{pH}$ = 11 with $15 \mathrm{~N}$ sodium hydroxide solution. It was heated under reflux for three hours. The mixture was then poured into distilled water and acidified with concentrated $\mathrm{HCl}$ to $\mathrm{pH}=5$. The resulting precipitate was filtered, washed with $5 \%$ sodium bicarbonate solution, dried, and purified by crystallization from methanole [22].

\section{General procedure for the synthesis of oxime ethers (Compounds D1-4) \\ Method A: $10 \mathrm{mmol}$ (2.52 g) 1-(2-naphthyl)-2-(triazol-} 1-yl)ethanone oxime (C) and $11 \mathrm{mmol}(0.75 \mathrm{~g})$ sodium ethoxide were stirred and refluxed for 30 minutes. Ethanol was evaporated in vacuo, the residue was dissolved in DMF, and $0.02 \mathrm{~mol}$ appropriate alkyl halide was added. The mixture was stirred at room temperature for four hours and then poured into ice water. The precipitate was filtered and crystallized from the appropri- 
ate solvents.

Method B: (Microwave synthesis) $10 \mathrm{mmol}$ (2.52 g) 1-(2-naphthyl)-2-(triazol-1-yl)ethanone oxime (C) and 11 mmol $(0.75 \mathrm{~g})$ sodium ethoxide were stirred and refluxed for 30 minutes. Ethanol was evaporated in vacuo, the residue was dissolved in DMF, and $0.02 \mathrm{~mol}$ appropriate alkyl halide was added. The mixture was irradiated in a microwave oven at $150 \mathrm{~W}$ for 10 minutes. The above purification method in Method A was also applied to this material.

\section{Antimicrobial Screening}

Broth microdilution testing was used to determine the MIC in accordance with the guidelines reported by the American Clinical and Laboratory Standards Institute (CLSI) $[23,24]$. The antimicrobial activity of the compounds was tested against four bacteria including two Gram (+) (Staphylococcus aureus ATCC 29213, Enterococcus faecalis ATCC 29212) and two Gram (-) microorganisms (Escherichia coli ATCC25922, Pseudomonas aeruginosa ATCC 27853) and for antifungal activities against three yeasts (Candida albicans ATCC 90028, Candida krusei ATCC 6258, Candida parapsilosis ATCC 90018). The tests were carried out using Mueller Hinton Broth (Difco, USA) for the bacteria and RPMI 1640 Broth (ICN-Flow, USA) for the fungi. Ciprofloxacine were used for antibacterial activity while fluconazole was used for antifungal activity as the reference compounds. The stock solutions of the compounds were prepared in di- methylsulfoxide. The solution in the test medium provided the required concentration ranging from 1024 to 1 $\mu \mathrm{g} / \mathrm{ml}$. All the inoculated plates were incubated at $350 \mathrm{C}$ and read visually after $16-20 \mathrm{~h}$ for bacteria but after 48 $\mathrm{h}$ for Candida species. The MIC values were recorded as the lowest concentrations of the substances that inhibit the visible growth of microorganisms.

\section{RESULTS and DISCUSSION}

\section{Chemistry}

In this study, as a continuation of our previous studies on (arylalkyl)azole derivatives, we aimed to synthesize some new triazol oxime ether derivatives with better pharmacokinetic profiles and then to evaluate their antimicrobial activities [7, 12, 20-22].

1-(2-naphthyl)-2-(1,2,4-triazol-1-yl)ethanone was obtained by alkylation of 1,2,4-triazole with 1-(2-naphthyl)2-(1,2,4-triazol-1-yl)-2-bromoethanone. The oxime was synthesized by the reaction of ketone and hydroxylamine hydrochloride. O-Alkylation of the oxime by appropriate alkyl halides gave the oxime ethers (Scheme 1). Sodium ethoxide was used as base to obtain oximates before alkylation. The structures and some properties of the synthesized compounds are given in Table 1 . Formation of the compounds was confirmed by IR, ${ }^{1} \mathrm{H}-\mathrm{NMR}$, Mass spectral data and elemental analysis.

In the IR spectral data, peaks of $\mathrm{C}=\mathrm{N}$ stretching at

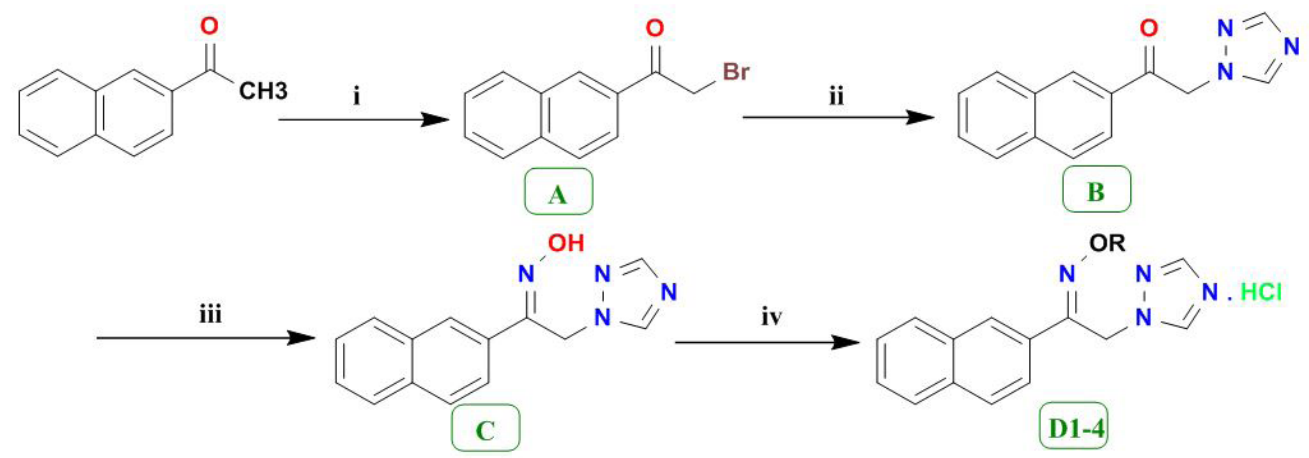

Reagents and conditions: (i) $\mathrm{Br}_{2}, \mathrm{CH}_{3} \mathrm{COOH}, 0-5^{\circ} \mathrm{C}$; (ii) $1 \mathrm{H}-1,2,4$-triazole, $\mathrm{DMF}, 0-5^{\circ} \mathrm{C}$; (iii) $\mathrm{NH}_{2} \mathrm{OH} . \mathrm{HCl}, \mathrm{C}_{2} \mathrm{H}_{5} \mathrm{OH}, \mathrm{NaOH}$ solution (pH 14); (iv) Method A: R-X, Na, $\mathrm{C}_{2} \mathrm{H}_{5} \mathrm{OH}, \mathrm{DMF}$, gHCl /Method B: MW $70^{\circ} \mathrm{C}, 500 \mathrm{~W}, \mathrm{R}-\mathrm{X}, \mathrm{Na}, \mathrm{CH}_{3} \mathrm{OH}, \mathrm{DMF}$.

Sheme 1. Synthesis of the compounds (D1-4) 
Table 1. Melting points, yields, molecular formula and molecular weights of the compounds D1-4.<smiles>CCCO/N=C(/Cn1cncn1)c1ccc2ccccc2c1</smiles>

\begin{tabular}{ccccccc}
\hline Comp. & $\mathbf{R}$ & Yield (\%) & $\begin{array}{c}\text { Microwave } \\
\text { Yield (\%) }\end{array}$ & MP ( $\mathbf{~} \mathbf{C})$ & $\begin{array}{c}\text { MW } \\
\mathbf{( g / m o l )}\end{array}$ & $\begin{array}{c}\text { Molecular } \\
\text { Formula }\end{array}$ \\
\hline D1 & Butyl & 65.53 & 52.19 & $160-1$ & 344.84 & $\mathrm{C}_{18} \mathrm{H}_{21} \mathrm{ClN}_{4} \mathrm{O}$ \\
\hline D2 & Isobutyl & 62.86 & 68.20 & $162-3$ & 344.84 & $\mathrm{C}_{18} \mathrm{H}_{21} \mathrm{ClN}_{4} \mathrm{O}$ \\
\hline D3 & Pentyl & 55.25 & 42.32 & 165 & 358.87 & $\mathrm{C}_{19} \mathrm{H}_{23} \mathrm{ClN}_{4} \mathrm{O}$ \\
\hline D4 & Hexyl & 62.33 & 52.33 & $166-7$ & 372.89 & $\mathrm{C}_{20} \mathrm{H}_{25} \mathrm{ClN}_{4} \mathrm{O}$ \\
\hline
\end{tabular}

$1500-1600 \mathrm{~cm}^{-1}, \mathrm{C}-\mathrm{O}$ stretching at 1100-1000 cm-1, and $\mathrm{N}-\mathrm{O}$ stretching bands at $1000-900 \mathrm{~cm}^{-1}$ were reported for the oxime ether derivatives $[25,26]$. According to this information, peaks of $\mathrm{C}=\mathrm{N}$ stretching at $1600-1510$ $\mathrm{cm}^{-1}, \mathrm{C}-\mathrm{O}$ stretching at $1086-1008 \mathrm{~cm}^{-1}$, and N-O stretching bands at $988-904 \mathrm{~cm}^{-1}$ were observed in the spectra of synthesized compounds (Figure 4). Observation of the $\mathrm{C}-\mathrm{O}$ band, which is not found in the oxime structure, shows the formation of the oxime ether structure. In addition, the absence of the $\mathrm{O}-\mathrm{H}$ band, which can be seen as wide as $3400-3600 \mathrm{~cm}^{-1}$, also indicates the formation of oxime ether. The $\mathrm{N}+-\mathrm{H}$ bending bands of the compound, which was obtained as the hydrochloric acid salt was poured over the tertiary nitrogen atom of the triazole ring, was found at $3211 \mathrm{~cm}^{-1}$. These findings are consistent with the literature and the traditional knowledge on the subject of IR absorptions of functio- nal groups [25, 26].

In the ${ }^{1} \mathrm{H}-\mathrm{NMR}$ spectrum of the synthesized compounds, the absence of the proton of the oxime group $(\mathrm{N}-\mathrm{OH})$ was observed at about $12 \mathrm{ppm}$, and the observation of the protons of the alkyl group indicate that this hydrogen is replaced by the alkyl group. All of the compounds synthesized were 2-naphthyl derivatives. The $\mathrm{H} 1$ proton of the naphthalene ring was observed as a singlet about 8.18-8.25 ppm, while the protons of $\mathrm{H}^{6,7}$ were observed as a multiplet between $7.34-7.58 \mathrm{ppm}$, and $\mathrm{H}^{3-5,8}$ were observed as a multiplet between $7.59-7.96 \mathrm{ppm}$ in accordance with literature data (Figure 5) [25, 26]. The aromatic ring protons in the structure of the synthesized compounds were observed between 7.40-7.80. $\mathrm{H}^{3}$, and $\mathrm{H}^{5}$ protons of the triazole ring had undergone a chemical shift to $8.71-9.10 \mathrm{ppm}$ and $8.27-8.59 \mathrm{ppm}$,

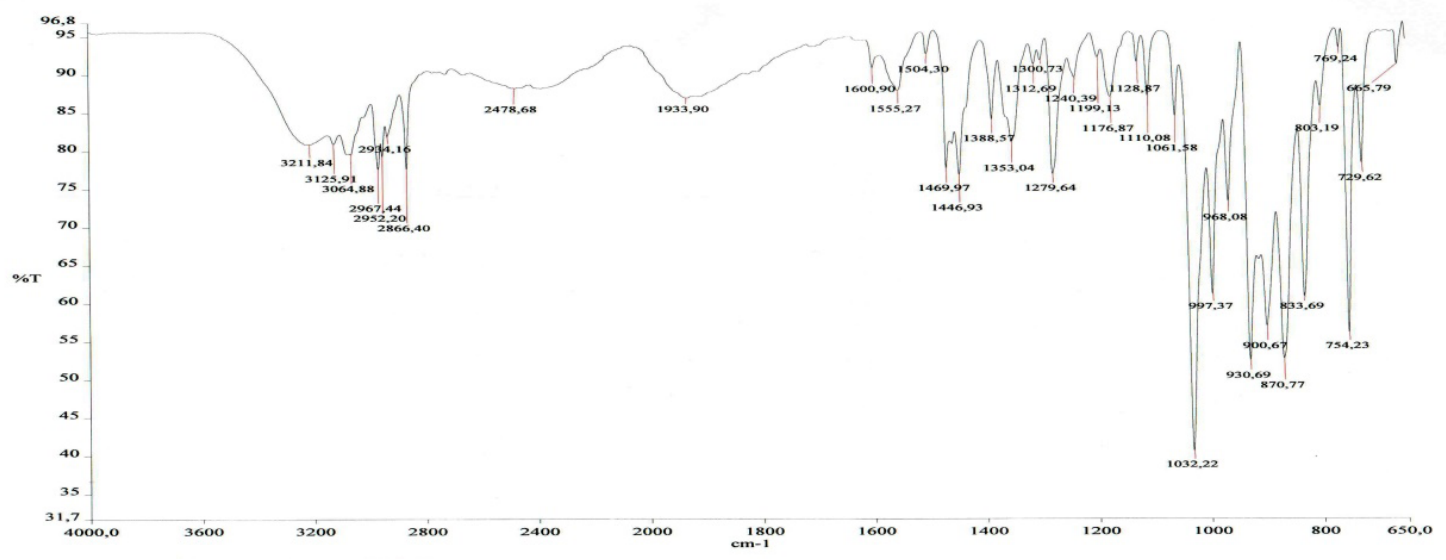

Figure 4. IR spectrum of compound 1-(2-Naphthyl)-2-(1,2,4-triazole-1-yl)ethanone oxime O-pentyl ether (D3). 


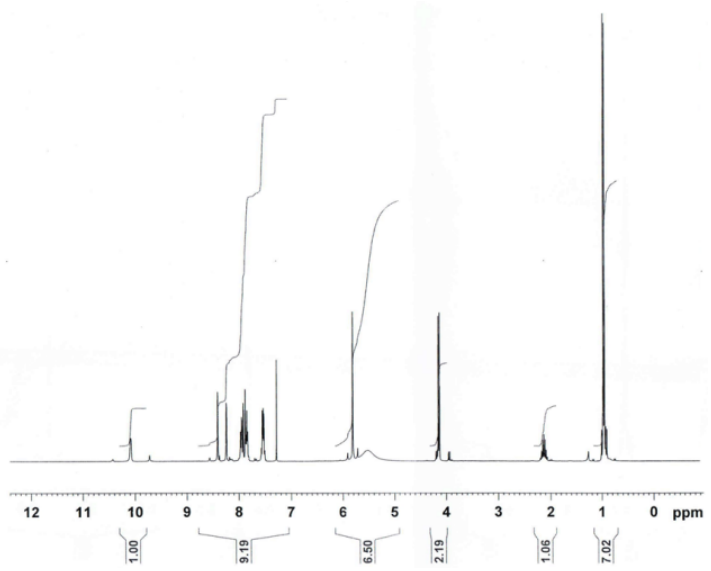

Figure 5. . 'H-NMR spectrum of 1-(2-Naphthyl)-2-(1,2,4-triazole-1-yl)ethanone oxime O-pentyl ether (D3).

respectively. Since the compounds were obtained as salts, the structure of the triazolium was formed and the peaks shifted to these values for this reason.

In our previous studies, due to the importance of geometric isomerism for biological activity, the configuration of 1-(2-naphthyl)-2-(pyrazol-1-yl)ethanone oxime O-isobutyl ether was also investigated through $X$-ray crystallography studies and identified as Z isomer (Figure 6) [12]. Subsequently, we compared the configuration of this compound to the other compounds by analogy of their ${ }^{1} \mathrm{H}-\mathrm{NMR}$ data. The isomer configuration of this type of oxime ether is usually assigned to the chemical shift of the singlet of the methylene protons between the oxime group and the pyrazole ring $(-\mathrm{C}(=\mathrm{N}-\mathrm{O}-)-$
$\mathrm{CH} 2-\mathrm{N}-)$, since these protons are unshielded by the presence of the adjacent oxime oxygen in the $\mathrm{Z}$ isomer [13]. Since the chemical shift of the singlet $(2 \mathrm{H})$ for methylene protons between oxime and 1,2,4-triazole in the ${ }^{1} \mathrm{H}$-NMR spectrum of 1-(2-naphthyl)-2-(pyrazol-1-yl) ethanone oxime O-isobutyl ether (5.55 ppm), and the chemical shift of the singlet $(2 \mathrm{H})$ for the same protons in the ${ }^{1} \mathrm{H}-\mathrm{NMR}$ spectra of the other oxime ethers (5.55$5.85 \mathrm{ppm}$ ) are almost equal, we can suggest that the other compounds are also in the $\mathbf{Z}$ configuration.

All spectral data of the compounds were in accordance with the assigned structures as shown following.

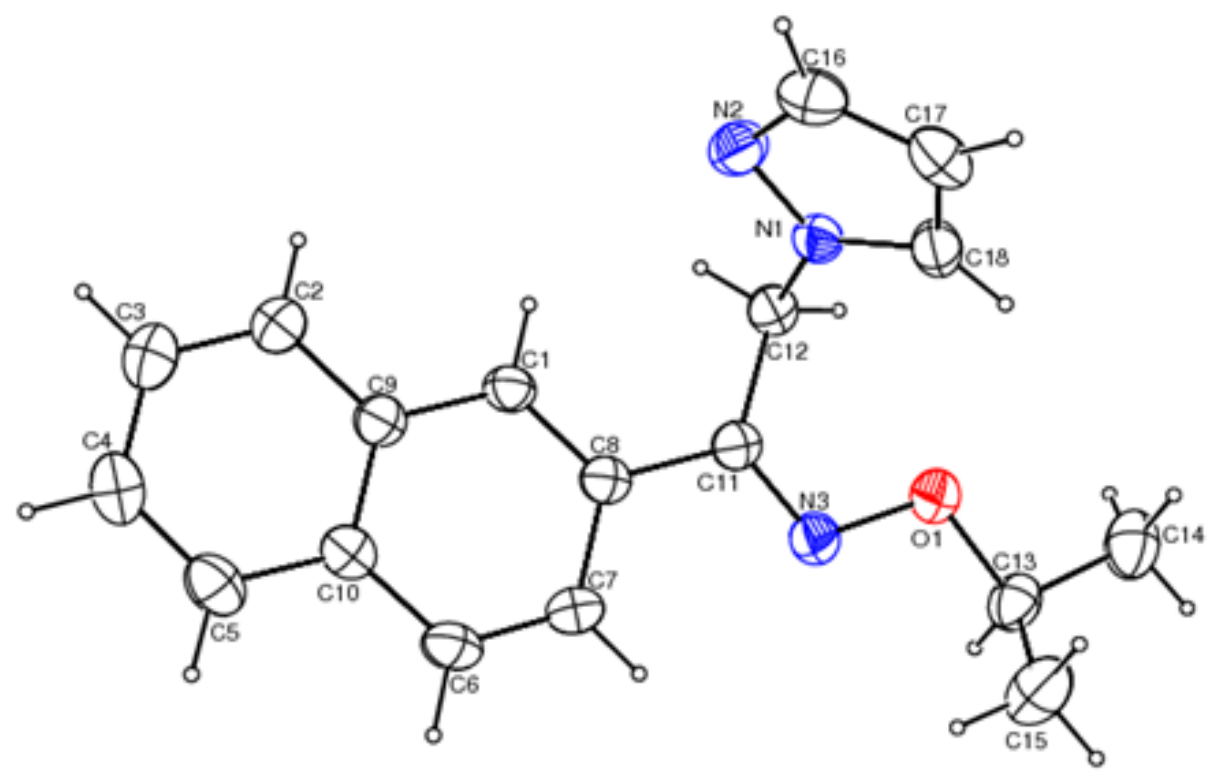

le oxime

Figure 5. . 'H-NMR spectrum of 1-(2-Naphthyl)-2-(1,2,4-triazole-1-yl)ethanone oxime O-pentyl ether (D3). 


\section{O-butyl ether (D1)}

Yield: 66\%; mp: $160-1^{\circ} \mathrm{C}$; IR (KBr, $\left.\mathrm{cm}^{-1}\right)$ : 923 (N-O), 1040 (C-O), $1536(\mathrm{C}=\mathrm{N}), 2955$ (aliphatic $\mathrm{C}-\mathrm{H}), 3055$ (aromatic C-H). ${ }^{1} \mathrm{H}-\mathrm{NMR}\left(\mathrm{CDCl}_{3}-\mathrm{d}, 300 \mathrm{MHz}\right): \delta 0.96\left(3 \mathrm{H} ; \mathrm{t}\right.$; $\left.-\mathrm{CH}_{3}\right)$, 1.33-1.45 (2H; m; $\left.\mathrm{CH}_{3}-\mathrm{CH}_{2}\right), 1.70-1.79\left(2 \mathrm{H} ; \mathrm{m} ;-\mathrm{CH}_{2}-\right.$ $\left.\mathrm{CH}_{2}-\mathrm{O}\right), 4.34\left(2 \mathrm{H} ; \mathrm{t} ;-\mathrm{CH}_{2}-\mathrm{O}\right), 5.81\left(2 \mathrm{H} ; \mathrm{s} ;-\mathrm{CH}_{2}-\mathrm{N}\right)$ and 7.52-8.39 (7H; m; naphthalene protons), $8.43(1 \mathrm{H} ; \mathrm{s}$; triazole $\mathrm{H} 5), 8.58(1 \mathrm{H}$; s; triazole $\mathrm{H} 3)$ and $10.68(1 \mathrm{H} ; \mathrm{s} ; \mathrm{HCl})$. HRMS (ESI) (M+H) m/z: 309.1701.

\section{1-(2-Naphthyl)-2-(1,2,4-triazole-1-yl)ethanone oxime O-isobutyl ether (D2)}

Yield: 63\%; mp: 162-3이 $\mathrm{IR}\left(\mathrm{KBr}, \mathrm{cm}^{-1}\right)$ : 923 (N-O), 1032 (C-O), $1555(\mathrm{C}=\mathrm{N}), 2967$ (aliphatic $\mathrm{C}-\mathrm{H}), 3064$ (aromatic $\mathrm{C}-\mathrm{H}), 3211(\mathrm{~N}-\mathrm{H}) .{ }^{1} \mathrm{H}-\mathrm{NMR}\left(\mathrm{CDCl}_{3}-\mathrm{d}, 300 \mathrm{MHz}\right): \delta 0.96$ $\left(6 \mathrm{H} ; \mathrm{d} ;-\mathrm{CH}_{3}\right), 2.08-2.17\left(1 \mathrm{H} ; \mathrm{m} ; \mathrm{CH}_{3}-\mathrm{CH}\right), 4.14(2 \mathrm{H} ; \mathrm{d}$; $\left.-\mathrm{CH}_{2}-\mathrm{O}\right), 5.81\left(2 \mathrm{H} ; \mathrm{s} ;-\mathrm{CH}_{2}-\mathrm{N}\right)$ and 7.28-7.97 (7H; m; naphthalene protons), $8.24(1 \mathrm{H}$; s; triazole $\mathrm{H} 5), 8.41(1 \mathrm{H}$; s; triazole $\mathrm{H} 3)$ and $10.09(1 \mathrm{H} ; \mathrm{s} ; \mathrm{HCl})$. HRMS (ESI) $(\mathrm{M}+\mathrm{H})$ m/z: 309.1708 .

\section{1-(2-Naphthyl)-2-(1,2,4-triazole-1-yl)ethanone oxime O-pentyl ether (D3)}

Yield: 55\%; mp: $165^{\circ} \mathrm{C}$; IR ( $\left.\mathrm{KBr}, \mathrm{cm}^{-1}\right)$ : 927 (N-O), 1036 (C-O), $1531(\mathrm{C}=\mathrm{N}), 2951$ (aliphatic $\mathrm{C}-\mathrm{H}), 3055$ (aromatic C-H). ${ }^{1} \mathrm{H}-\mathrm{NMR}\left(\mathrm{CDCl}_{3}-\mathrm{d}, 300 \mathrm{MHz}\right): \delta 0.92\left(3 \mathrm{H} ; \mathrm{t} ;-\mathrm{CH}_{3}\right)$, 1.31-1.40 (4H; m; $\left.\mathrm{CH}_{3}-\mathrm{CH}_{2}-\mathrm{CH}_{2}\right), 1.72-1.81\left(2 \mathrm{H} ; \mathrm{m} ;-\mathrm{CH}_{2}-\right.$ $\left.\mathrm{CH}_{2}-\mathrm{CH}_{2}-\mathrm{O}\right), 4.33\left(2 \mathrm{H} ; \mathrm{t} ;-\mathrm{CH}_{2}-\mathrm{O}\right), 5.82\left(2 \mathrm{H} ; \mathrm{s} ;-\mathrm{CH}_{2}-\mathrm{N}\right)$, 7.50-8.25 (7H; m; naphthalene protons), $8.42(1 \mathrm{H}$; s; triazole $\mathrm{H} 5), 8.58(1 \mathrm{H}$; s; triazole $\mathrm{H} 3)$ and $10.38(1 \mathrm{H} ; \mathrm{s} ; \mathrm{HCl})$. HRMS (ESI) $(\mathrm{M}+\mathrm{H}) \mathrm{m} / \mathrm{z}: 323.1856$.

\section{1-(2-Naphthyl)-2-(1,2,4-triazole-1-yl)ethanone oxime}

\section{O-hexyl ether (D4)}

Yield: 62\%; mp: $166-7^{\circ} \mathrm{C}$; IR $\left(\mathrm{KBr}, \mathrm{cm}^{-1}\right)$ : 927 (N-O), 1035 (C-O), $1527(\mathrm{C}=\mathrm{N}), 2952$ (aliphatic $\mathrm{C}-\mathrm{H}), 3054$ (aromatic C-H). ${ }^{1} \mathrm{H}-\mathrm{NMR}\left(\mathrm{CDCl}_{3}-\mathrm{d}, 300 \mathrm{MHz}\right): \delta 0.90\left(3 \mathrm{H} ; \mathrm{t} ;-\mathrm{CH}_{3}\right)$, 1.24-1.42 (6H; m; $\left.\mathrm{CH}_{3}-\mathrm{CH}_{2}-\mathrm{CH}_{2}-\mathrm{CH}_{2}\right), 1.72-1.80(2 \mathrm{H} ; \mathrm{m}$; $\left.-\mathrm{CH}_{2}-\mathrm{CH}_{2}-\mathrm{CH}_{2}-\mathrm{O}\right), 4.34\left(2 \mathrm{H} ; \mathrm{t} ;-\mathrm{O}-\mathrm{CH}_{2}\right), 5.81\left(2 \mathrm{H} ; \mathrm{s} ;-\mathrm{CH}_{2}-\mathrm{N}\right)$ and 7.56-8.25 (7H; m; naphthalene protons), $8.44(1 \mathrm{H} ; \mathrm{s}$; triazole $\mathrm{H} 5), 8.58(1 \mathrm{H}$; s; triazole $\mathrm{H} 3)$ and $10.23(1 \mathrm{H}$; s; $\mathrm{HCl})$. HRMS (ESI) $(\mathrm{M}+\mathrm{H}) \mathrm{m} / \mathrm{z}: 337.2020$.

\section{Antimicrobial Activity}

Antibacterial and antifungal activities of the synthesized Compounds D1-4 as MIC values were given in Table 2. The screening data demonstrate that 1-(2-Naphthyl)-2(1,2,4-triazole-1-yl)ethanone oxime $\mathrm{O}$-butyl ether (D1) shows the best antibacterial activity against $S$. aureus and $P$. aeruginosa among the synthesized compounds. All the studied compounds were found to be more effective against $S$. aureus than the other tested bacteria. All four of the synthesized compounds against to $C$. krusei had the same antifungal activity (the MIC value of $256 \mu \mathrm{g} / \mathrm{mL}$ ) against to all Candida strains, except for 1-(2-Naphthyl)-2-(1,2,4-triazole-1-yl)ethanone oxime $\mathrm{O}$-isobutyl ether (D2). Contrary to our previous research, in this study it was observed that the activity of these compounds decreased as the carbon chain increased. The compounds with a pyrazole ring were less potent compared to the activities of their triazole analogs; also, an oxime ester group instead of oxime ether in the structure caused significant decrease in the antimicrobial activity [12-15].

\section{CONCLUSION}

Table 2. MIC values of the Compounds D1-4 against to the bacterial and fungal laboratory strains.

\begin{tabular}{cccccccc}
\hline & \multicolumn{3}{c}{ Antibacterial activities $(\mu \mathrm{g} / \mathrm{mL})$} & \multicolumn{3}{c}{ Antifungal activites $(\mu \mathrm{g} / \mathrm{mL})$} \\
\cline { 2 - 8 } Comp. & $\begin{array}{c}\text { S. aureus } \\
\text { ATCC 29213 }\end{array}$ & $\begin{array}{c}\text { P. aeruginosa } \\
\text { ATCC 27853 }\end{array}$ & $\begin{array}{c}\text { E. faecalis } \\
\text { ATCC 29212 }\end{array}$ & $\begin{array}{c}\text { E. coli } \\
\text { ATCC 25922 }\end{array}$ & $\begin{array}{c}\text { C. albicans } \\
\text { ATCC 90028 }\end{array}$ & $\begin{array}{c}\text { C. } \text { krusei } \\
\text { ATCC } 6258\end{array}$ & $\begin{array}{c}\text { ATCC } \\
90018\end{array}$ \\
\hline D1 & 64 & 64 & 256 & 512 & 256 & 256 & 256 \\
\hline D2 & 1024 & 512 & 512 & 512 & 256 & 512 & 256 \\
\hline D3 & 256 & 512 & 512 & 512 & 256 & 256 & 256 \\
\hline D4 & 512 & 512 & 512 & 512 & 256 & 256 & 256 \\
\hline Ciprofloxacine & 0.125 & 0.125 & 0.5 & 0.0625 & - & - & - \\
\hline Fluconazole & - & - & & - & 0.5 & 16 & 1 \\
\hline
\end{tabular}


To sustain our research interest in developing novel nafimidone-like antimicrobial compounds and establishing new relationships between their structure and activity, we designed and synthesized four new nafimidone oxime ether derivatives and evaluated their antimicrobial activities. None of them exhibited notable antibacterial and antifungal activity. However, 1-(2-naphthyl)-2(1,2,4-triazole-1-yl)ethanone oxime 0 -butyl ether (D1) had relatively better antibacterial activity among the compounds ( $\mathrm{MIC}=64 \mu \mathrm{g} / \mathrm{mL})$.

In this study, triazole oxime ethers have been synthesized using both conventional and microwave methods. The reaction time of the final step was four hours and ten minutes for the conventional and microwave methods, respectively. Shortening the reaction time was a major advantage for us, but the yields were not as high as expected.

\section{ACKNOWLEDGEMENTS}

We owe to Nagihan Kaya and Fatime Beytüt, who are undergraduate students for their help in the synthesis studies.

\section{REFERENCES}

1. A.S. Hassan, D.M. Masoud, F.M. Sroor, A.A. Askar, Synthesis and biological evaluation of pyrazolo[1,5-a]pyrimidine-3 carboxamide as antimicrobial agents, Med. Chem. Res., 26 (2017) 2909-2919.

2. I. Roca, M. Akova, F. Baquero, J. Carlet, M. Cavaleri, S Coenen, J. Cohen, D. Findlay, I. Gyssens, O.E. Heure, G. Kahlmeter, The global threat of antimicrobial resistance: science for intervention, New Microbes New Infect., 6 (2015) 22-29.

3. M.A. Abdelrahman, I. Salama, M.S. Gomaa, M.M. Elaasser, M.M. Abdel-Aziz, D.H. Soliman, Design, synthesis and 2D QSAR study of novel pyridine and quinolone hydrazone derivatives as potential antimicrobial and antitubercular agents, Eur. J. Med. Chem., 138 (2017) 698-714.

4. S. Silva, M. Negri, M. Henriques, R. Oliveira, D.W. Williams, J. Azeredo, Candida glabrata, Candida parapsilosis and Candida tropicalis: biology, epidemiology, pathogenicity and antifungal resistance, FEMS Microbiol. Rev., 36/2 (2012) 288-305.

5. M. Janeczko, O.M. Demchuk, D. Strzelecka, K. Kubinski, M. Masłyk, New family of antimicrobial agents derived from 1,4-naphthoquinone., Eur. J. Med. Chem., 124 (2016) 1019 1025.

6. S. Concilio, L. Sessa, A.M. Petrone, A. Porta, R. Diana, P.
Iannelli, S. Piotto, Structure Modification of an Active AzoCompound as a Route to New Antimicrobial Compounds, Molecules, 22 (2017) 875.

7. A. Karakurt, M.D. Aytemir, J.P. Stables, M. Özalp, F.B. Kaynak, S. Özbey, S. Dalkara, Synthesis of some oxime ether derivatives of 1-(2-naphthyl)-2-(1,2,4-triazol-1-yl)ethanone and their anticonvulsant and antimicrobial activities, Arch. Pharm. (Weinheim, Germany), 339 (2006) 513-520.

8. S. Kaping, I. Boiss, L.I. Singha, P. Helissey, J.N. Vishwakarma, A facile, regioselective synthesis of novel 3-(N-phenylcarboxamide)pyrazolo[1,5-a]pyrimidine analogs in the presence of $\mathrm{KHSO} 4$ in aqueous media assisted by ultrasound and their antibacterial activities, Mol. Divers., 20 (2016) 379-390.

9. S. Deshmukh, K. Dingore, V. Gaikwad, M. Jachak, An efficient synthesis of pyrazolo[1,5-a]pyrimidines and evaluation of their antimicrobial activity, J Chem. Sci., 128 (2016) 14591468.

10. J. Zhang, J.F. Peng, T. Wang, P. Wang, Z.T. Zhang, Synthesis, crystal structure, characterization and antifungal activity of pyrazolo[1,5-a]pyrimidines derivatives, J. Mol. Struct., 1120 (2016) 228-233.

11. A.N. Ambhore, R.D. Kamble, P.P. Mogle, S.V. Hese, S.N. Kadam, M.J. Hebade, S.S. Kamble, R.N. Gacche, B.S. Dawane1, An Efficient One-pot Synthesis of some New Pyrazolyl Appended 1,3,4-Oxadiazole Derivatives as Antibacterial and Antioxidant agents, Der. Pharma. Chemica, 9/9 (2017) 48-56.

12. Z. Özdemir, A. Karakurt, Ü. Çalış, S. Günal, Ş. Işık, Z.S. Şahin, S. Dalkara, Synthesis, anticonvulsant and antimicrobial activities of some new[1-(2-naphthyl)-2(pyrazol-1-yl) ethanone]oximeethers, Med. Chem., 11 (2015) 41-49.

13. A. Karakurt, S. Dalkara, M. Özalp, S. Özbey, E. Kendi, J.P. Stables, Synthesis of some 1-(2-naphthyl)-2-(imidazole-1$\mathrm{yl}$ )ethanone oxime and oxime ether derivatives and their anticonvulsant and antimicrobial activities, Eur. J. Med. Chem., 36 (2001) 421-33.

14. i.S. Doğan, S. Saraç, S. Sari, D. Kart, G.Ş. Eşsiz, i. Vural, S. Dalkara, New azole derivatives showing antimicrobial effects and their mechanism of antifungal activity by molecular modeling studies, Eur. J. Med. Chem., 21/130 (2017) 124-138.

15. A. Karakurt, M.A. Alagöz, B. Sayoğlu, Ü. Calış, S. Dalkara, Synthesis of some novel 1-(2-naphthyl)-2-(imidazol-1-yl) ethanone oxime ester derivatives and evaluation of their anticonvulsant activity, Eur. J. Med. Chem., 57 (2012) 275282.

16. M. Larhed, A. Hallberg, Microwave-assisted high-speed chemistry: a new technique in drug discovery, Drug Discov. Today, 6/8 (2001) 406-416.

17. P. Lidström, J. Tierney, B. Wathey, J. Westman, Microwave assisted organic synthesis-a review, Tetrahedron, 57 (2001) 9225-9283.

18. B.L. Hayes, Recent Advances in Microwave-Assisted Synthesis, Aldrichimica Acta, 37 (2004) 66-76.

19. S. Balalaie, M.M. Hashemi, M. Akhbari, A novel one-pot synthesis of tetrasubstituted imidazoles under solvent-free conditions and microwave irradiation, Tetrahedron Lett., 44 (2003) 1709-1711.

20. T. Immediata, A.R. Day, Beta-Naphtyl Derivatives of Ethanolamine and N-Substituted Ethanolamines, J. Org. Chem., 5 (1940) 512-27.

21. Ü. Çalış, S. Dalkara, M. Ertan, R. Sunal, The Significance of the Imidazole Ring in Anticonvulsant Activity of (Arylalkyl) imidazoles, Arch. Pharm. (Weinheim), 321 (1988) 841-846.

22. F. Özkanlı, S. Dalkara, Ü. Çalış, A. Willke, Synthesis of Some 
$\mathrm{N}$-Arylazole Acetamide Derivatives and Their Anticonvulsant and Antimicrobial Activities, ArzneimmittelForsch., 44/8 (1994) 920-924.

23. Clinical and Laboratory Standards Institute, Approved StandardSeventh Edition, CLSI Document M7-A7, Pennsylvania, https://www.clsi.org/media/1632/m07a10_ sample.pdf, 2003 (accessed 24.05.2018)

24. Clinical and Laboratory Standards Institute, Approved
StandardSecond Edition. NCCLS document M27-A2, Pennsylvania, 2002.

25. J. Gootjes, A.B.H. Funcke, H. Timmerman, W.TH. Nauta, Experiments in the $5 \mathrm{H}$-Dibenzola, d]cycloheptene Series, ArzneimmittelForsch., 22/12 (1972) 2070-2073.

26. E. Pretsch, T. Clerk, J. Seibl, W. Simon, Tables of Spectral Data for Structure Determination of Organic Compounds, Springer- Verlag, Berlin, 1983. 